\title{
Politike roditeljskih dopusta, sustavi ranog i predškolskog odgoja i obrazovanja, rodne i društvene nejednakosti u postjugoslavenskim zemljama
}

UDK: 364.421.44:364.013(497.1-89)

doi: 10.3935/rsp.v28i3.1879

Pristup je dobro plaćenim roditeljskim dopustima te priuštivim i kvalitetnim uslugama ranog i predškolskog odgoja i obrazovanja (RPOO) nužan u fazi ranog roditeljstva, a kako bi se stvorile pretpostavke za ravnopravno sudjelovanje roditelja na tržištu rada i u skrbi te omogućile jednake mogućnosti svakom djetetu. Unatoč tome, brojni roditelji i djeca nemaju (adekvatan) pristup tim mjerama. Štoviše, uz rodne nejednakosti u skrbi i zaposlenosti, studije rastuće ukazuju na tzv. efekt svetog Mateja (eng. Matthew effect) u korištenju roditeljskih dopusta i usluga RPOO-a, odnosno kako obitelji u nepovoljnijem položaju imaju manje koristi of plaćenih roditeljskih dopusta i usluga RPOO-a (Ghysels i van Lancker, 2011.; Pavolini i van Lancker, 2018.; McKay i sur., 2016.). Takav se ishod primarno povezuje sa samim dizajnom politika roditeljskih dopusta i sustava RPOO-a, a na što ukazuje i ovdje iznesena analiza nastala u okviru InCARE projekta. ${ }^{1}$ Analiza ističe višedimenzionalan karakter te kompleksnost sustava roditeljskih dopusta i RPOO-a u postjugoslavenskim zemljama, a ponajprije da sama struktura te dizajn svake pojedine dimenzije kako politika roditeljskih dopusta tako i sustava RPOO-a može imati različite i nerijetko suprotstavljene učinke na rodne i društvene nejednakosti u skrbi i zaposlenosti (detaljnije u Dobrotić, 2019., 2021.).

\section{POLITIKE RODITELJSKIH DOPUSTA, RODNE I DRUŠTVENE NEJEDNAKOSTI}

Dopusti usmjereni roditeljima (eng. parenting leaves) najčešće se dijele na: 1) rodiljni, 2) očev i 3) roditeljski dopust (OECD, 2011.; Koslowski i sur., 2020.). Rodiljni dopust (eng. maternity leave) u pravilu je isključivo pravo majke, koje se koristi neposredno prije i nakon poroda, a primarna mu je svrha očuvanje zdravlja majke i djeteta. Slično tome, otac/partner/partnerica neposredno nakon rođenja djeteta može ostvariti pravo na očev dopust (eng. paternity leave). Roditeljski dopust (eng. parental leave) pravo je oba roditelja koje u pravilu slijedi odmah po završetku rodiljnog dopusta. Može se koristiti u cijelosti ili u dijelovima do zakonom propisane dobi djeteta (npr. osme godine). Roditeljski dopust može

\footnotetext{
${ }^{1}$ InCARE projekt Social and gender inequalities in care: Childcare-related policies and parenting practices in the post-Yugoslav countries and the role of policy ideas financiran je sredstvima iz programa za istraživanje i inovacije EU-a Obzor 2020., u sklopu sporazuma o dodjeli bespovratnih sredstava Marie Skłodowska-Curie Actions br. 786826. Ovdje se iznose dijelovi završnog istraživačkog izvješća i policy briefa dostupni na mrežnim stranicama projekta: https://www.incare-pyc.eu/resources./
} 
biti definiran kao obiteljsko pravo koje roditelji koriste sukladno dogovoru ili kao individualno pravo svakog roditelja - prenosivo ili (djelomice) neprenosivo s jednog roditelja na drugog. Neprenosivi mjeseci roditeljskog dopusta nazivaju se kvotama i, ukoliko ih roditelj kojem su namijenjeni ne iskoristi, propadaju. Uz samu strukturu dopusta te njihovu rodnu dimenziju, sheme se dopusta razlikuju u pogledu trajanja dopusta, visine naknada za vrijeme dopusta, fleksibilnih mogućnosti korištenja dopusta te (kriterija) pristupa plaćenim dopustima (Koslowski i sur., 2020.) i ovisno o svakom ovom elementu (ili kombinaciji) mogu imati različite implikacije na mogućnosti roditelja da (kontinuirano) sudjeluju na tržištu rada ili u pružanju skrbi.

Predugi ili prekratki roditeljski dopusti imaju negativan učinak na položaj žena na tržištu rada. Iako istraživanja ne daju jednoznačan odgovor glede optimalnog trajanja dopusta, smatra se kako plaćeni dopusti u trajanju od oko godinu dana vode pozitivnijim učincima vezanima uz sudjelovanje i položaj žena na tržištu rada te dobrobit djece. Duži dopusti destimuliraju (ponovni) ulazak žena na tržište rada i »nagrizaju « ljudski kapital, odnosno rezultiraju gubitkom znanja i vještina te negativno utječu na njihovu buduću zaradu i razvoj karijera. Štoviše, vjerojatnije je da će duge dopuste koristiti majke nižeg obrazovnog statusa ili migrantice što produbljuje društvene nejednakosti. Jako kratki dopusti također doprinose »ispadanju « žena s tržišta rada (Galtry i Callister, 2005.; Dobrotić, 2015.; Ferragina, 2020.).

Individualno i neprenosivo pravo očeva na dobro plaćen dopust vodi rodno ravnopravnijoj raspodjeli brige za djecu. Istraživanja jasno pokazuju kako je upravo individualno, neprenosivo pravo očeva na dobro plaćen dopust (očevi dopusti i/li očeve kvote) ključni element dizajna politike roditeljskih dopusta koji može doprinijeti većem korištenju dopusta od strane očeva, a time i promjeni rodnih praksi u skrbi za djecu (O’Brien i Wall, 2017.; Dobrotić i Varga, 2018.). Pozitivni se učinci javljaju već kod kraćeg korištenja dopusta te su očevi koji su bili na dopustima dužima od dva tjedna uključeniji u poslove vezane uz brigu o djetetu (npr. hranjenje, mijenjanje pelena, dizanje noću, kupanje i čitanje knjiga), a učinak je veći kod dopusta dužih od mjesec dana te $u$ situacijama kada očevi sami koriste dopuste (Huerta i sur., 2014.; Brandth i Kvande, 2018.). Dobro se plaćenim dopustima smatraju dopusti plaćeni $80 \%$ ili više prethodne plaće (npr. Gornick i Meyers, 2003.).

Politike fleksibilnosti i »izbora« ne doprinose rodnoj ravnopravnosti. Rodno neutralne politike (npr. obiteljsko pravo na roditeljski dopust koji roditelji raspodjeljuju sukladno vlastitim preferencama), često nazivane »politikama izbora« zapravo potiču maternalističku kulturu te primarnu odgovornost za skrb prebacuju na žene. To dodatno pojačava nedostupnost i nepriuštivost javnih usluga, a posebice kod žena nižeg socioekonomskog statusa koje raspolažu s manje resursa te imaju slabije mogućnosti »izbora« (Blofield i Franzoni, 2015.; Koslowski i sur., 2019.). Slično, fleksibilne mogućnosti korištenja roditeljskih dopusta (npr. rad u nepunom radnom vremenu) nužno ne doprinose boljem usklađivanju obiteljskih obaveza i plaćenog rada, a koristi primarno ima radno okruženje (npr. roditelji rade daleko više nego što su ugovorili). Također, doprinose stresu, dok neka istraživanja pokazuju kako očevo fleksibilno korištenje roditeljskih dopusta ne doprinosi većoj rodnoj ravnopravnosti u skrbi (Koslowski i sur., 2019.; Brandth i Kvande, 2019.).

Sheme roditeljskih dopusta (ali i sustavi RPOO-a) kreirane oko iskustva »tradicionalno« zaposlenih roditelja ograničavaju prava roditelja u netipičnoj i/li nesigurnoj zaposlenosti. Studije rastuće ukazuju kako u mnogim zemljama politike roditeljskih dopusta i RPOO-a ponajprije podupiru »obitelji dvostrukog 
hranitelja te pristup (adekvatnim) pravima vežu uz status »tradicionalne « zaposlenosti koja podrazumijeva stabilno i sigurno zaposlenje. Time se sužava krug potencijalnih korisnika prava, posebice u kontekstu »smanjivanja« socijalne države te širenja »nestandardnih « oblika zaposlenosti (usp. McKay i sur., 2016.; Dobrotić i Blum, 2019., 2020.). Uvjetovanje pristupa dopustima i uslugama striktnim zahtjevima vezanima uz zaposlenje (npr. dugim i stabilnim razdobljima prethodnog socijalnog osiguranja) i zastarjelim konceptima radnih odnosa vodi tome da (budući) roditelji koji se sve češće nalaze u netipičnoj ili nesigurnoj zaposlenosti nailaze na prepreke pri ostvarivanju temeljnih roditeljskih prava (usp. McKay i sur., 2016.; van Lancker i Ghysels, 2016; Dobrotić i Blum, 2019., 2020.; Blum i Dobrotić, 2021.).

\section{Politike roditeljskih dopusta u postjugoslavenskim zemljama}

Komparativno gledano, postjugoslavenske zemlje karakterizira rana državna intervencija u područje politika roditeljskih dopusta, a koje se intenzivnije razvijaju tijekom socijalističkog razdoblja. Razvoj dopusta bio je primarno usmjeren prema uspostavi i širenju prava zaposlenih majki. Okvirnim se zakonodavstvom, koje je vrijedilo za područje cijele Jugoslavije, pravo na rodiljni dopust plaćen u visini prethodne plaće s prvobitnih 2,8 mjeseci postepeno produžava na devet mjeseci (do 1989. godine). Neke su zemlje razvile izdašnije sheme te, primjerice, krajem 1980-ih u Sloveniji i Bosni i Hercegovini plaćeni dopusti traju 12, a u Hrvatskoj 13 mjeseci (detaljnije u Dobrotić, 2019., 2021.). Dominirali su rodiljni dopusti namijenjeni isključivo zaposlenim majkama, a koje su od 1970-ih u iznimnim situacijama mogli koristiti oče- vi (npr. smrt ili bolest majke, majka nije u mogućnosti brinuti za dijete ili je napustila dijete). Samo su Slovenija i Hrvatska uvele shemu koja je razlikovala »rodiljni « od »dodatnog rodiljnog dopusta $\aleph^{2}$ te u nešto većoj mjeri otvorile mogućnost korištenja dopusta očevima. Naime, očevi su u Sloveniji (od 1975. godine) i Hrvatskoj (od 1978. godine) mogli koristiti pravo na »dodatni rodiljni dopust« ukoliko bi im majka prenijela svoje pravo na plaćeni dopust. Iako Hrvatska i Slovenija na taj način otvaraju veću mogućnost dogovora među partnerima, dopust ipak ostaje primarno pravo majke koja zadržava tzv. gate-keeping funkciju. Kako na taj način definirane sheme dopusta ne vode rodno ravnopravnijem korištenju dopusta (vidi Dobrotić i Varga, 2018.), ne dolazi do bitnijih promjena u roditeljskim praksama i dopuste gotovo uvijek koriste majke (vidi Korintus i Stropnik, 2009.).

Razlike među državama u razvoju politika roditeljskih dopusta postaju izraženije nakon 1990. godine, jasno odražavajući specifične tranzicijske okolnosti u kojima su se pojedine zemlje našle. Sve zemlje zadržavaju dopuste naslijeđene iz socijalističkog razdoblja te ih postepeno nadograđuju nekim od naredne tri skupine elemenata: pronatalitetnim elementima (duži dopusti za roditelje s više djece); elementima rodne ravnopravnosti (širenje opsega prava očeva) i/li elementima inkluzivnosti (širenje prava na nove skupine roditelja). Osim toga, uočavaju se i reforme kojima se (ne)posredno smanjuje visina rodiljnih/roditeljskih naknada bilo putem direktnog smanjivanja visine naknada (uključujući i njihovo ukidanje) bilo putem uvođenja gornjih granica na visinu naknada (najviše pogađa osobe s višim primanjima) ili promjena u kriterijima pristupa pravu na (punu) naknadu (najviše pogađa roditelje s nestabilnim radnim karijerama) (detaljnije u Dobrotić, 2019.,

\footnotetext{
${ }^{2}$ Zakonodavac je u to vrijeme za dopust koji je slijedio nakon rodiljnog dopusta koristio termin »dodatni rodiljni dopust« (u Sloveniji od 1986. godine rodno neutralniji termin »dopust za njegu djeteta«).
} 
2021.). Glavna su obilježja današnjih sustava sažeta kroz naredne tri točke:

(1) Roditeljski dopusti u postjugoslavenskim zemljama u pravilu su usmjereni majkama te nedovoljno ublažavaju rodne nejednakosti u skrbi i zaposlenosti. Promjene su na rodnoj dimenziji dopusta bile izrazito spore i jasan odraz različite dinamike pregovora i pristupanja EU-u te potrebe usklađivanja s direktivom o roditeljskom dopustu (usp. Tablica 1. i Slika 1.). ${ }^{3}$ Slovenija uvodi pravo na očev dopust (u implementaciji od 2003. godine), ${ }^{4}$ a Hrvatska (od 2013. godine) dvomjesečne ${ }^{5}$ i Crna Gora (od 2019. godine) jednomjesečne kvote unutar sheme roditeljskog dopusta. No, samo se u Sloveniji i Crnoj
Gori radi o dobro plaćenim dopustima koji mogu doprinijeti rodno ravnopravnijoj raspodjeli obaveza skrbi u privatnoj sferi (usp. Dobrotić i Varga, 2018.). U preostalim zemljama, uključivši i Srbiju koja većinu rodiljnog dopusta prevodi u »dopust za njegu djeteta«, dopusti i dalje ostaju definirani kao primarno pravo majke, a koje može koristiti i otac. Važno je istaknuti i kako prekomjerno oslanjanje na elemente dizajna politika roditeljskih dopusta koji najveći dio »tereta« skrbi prebacuju na žene te polaženje od iskustva raznospolnih partnera pri kreiranju kvota vodi manjem opsegu prava »netradicionalnih « obitelji u većini zemalja (npr. jednoroditeljske obitelji, istospolni (muški) parovi).

Tablica 1.

Europski javnopolitički okvir na području politika roditeljskih dopusta i usluga ranog i predškolskog odgoja i obrazovanja

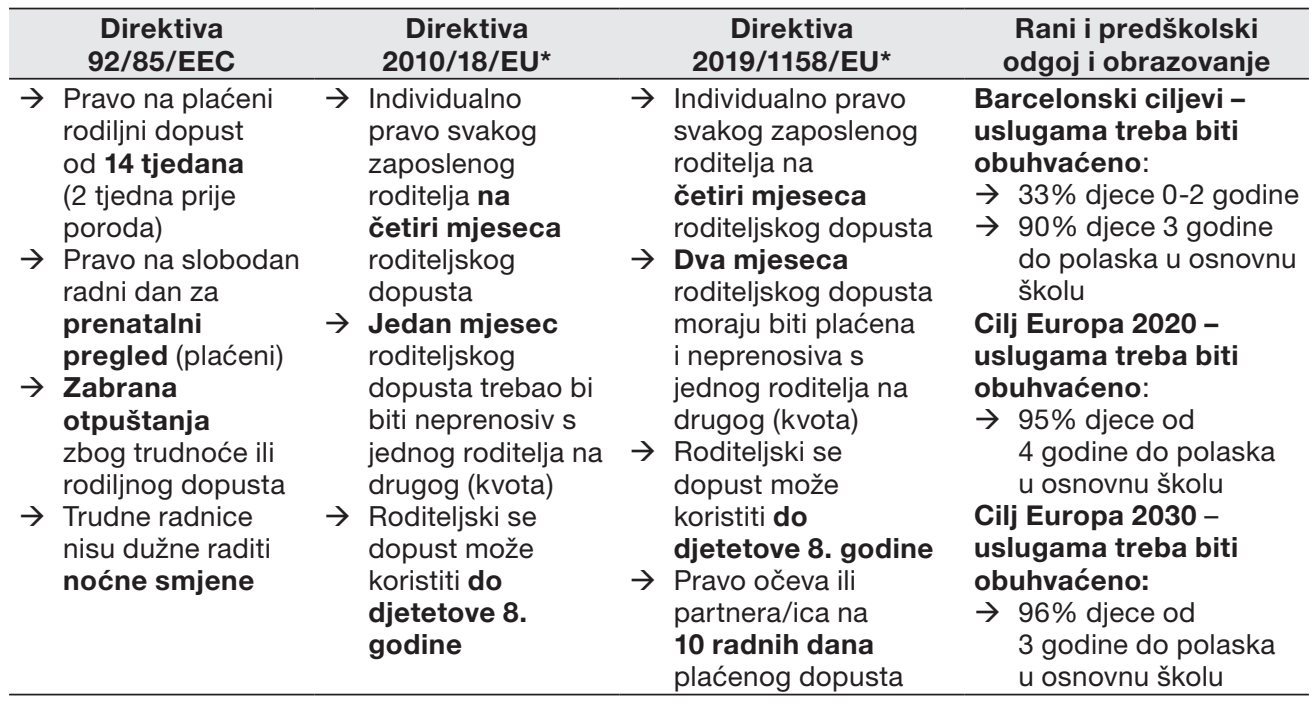

* Direktivu 2019/1158/EU zemlje članice moraju prevesti u nacionalno zakonodavstvo do 2. kolovoza 2022. godine (osim odredbe o dva mjeseca plaćenog roditeljskog dopusta gdje se zakonodavstvo zemalja članica mora uskladiti do 2. kolovoza 2024. godine). Ova će direktiva zamijeniti Direktivu 2010/18/EU.

Izvor: Dobrotić (2021.)

\footnotetext{
${ }^{3}$ Svim zemljama predstoje dodatna usklađivanja s novom direktivom o ravnoteži između poslovnog i privatnog života roditelja i pružatelja skrbi, a koja teži dodatno ojačati rodnu dimenziju dopusta (usp. Tablica 1. i Slika 1.). ${ }^{4}$ Slovenija nije uvela očeve kvote, a jedan je mjesec roditeljskog dopusta definirala kao isključivo pravo majke.

${ }^{5}$ To ne vrijedi za očeve čija je partnerica nezaposlena/neaktivna. Također, kvote su u Hrvatskoj slabije plaćene.
} 
Slika 1.

Struktura plaćenih dopusta usmjerenih roditeljima u postjugoslavenskim zemljama (trajanje dopusta za prvo dijete)

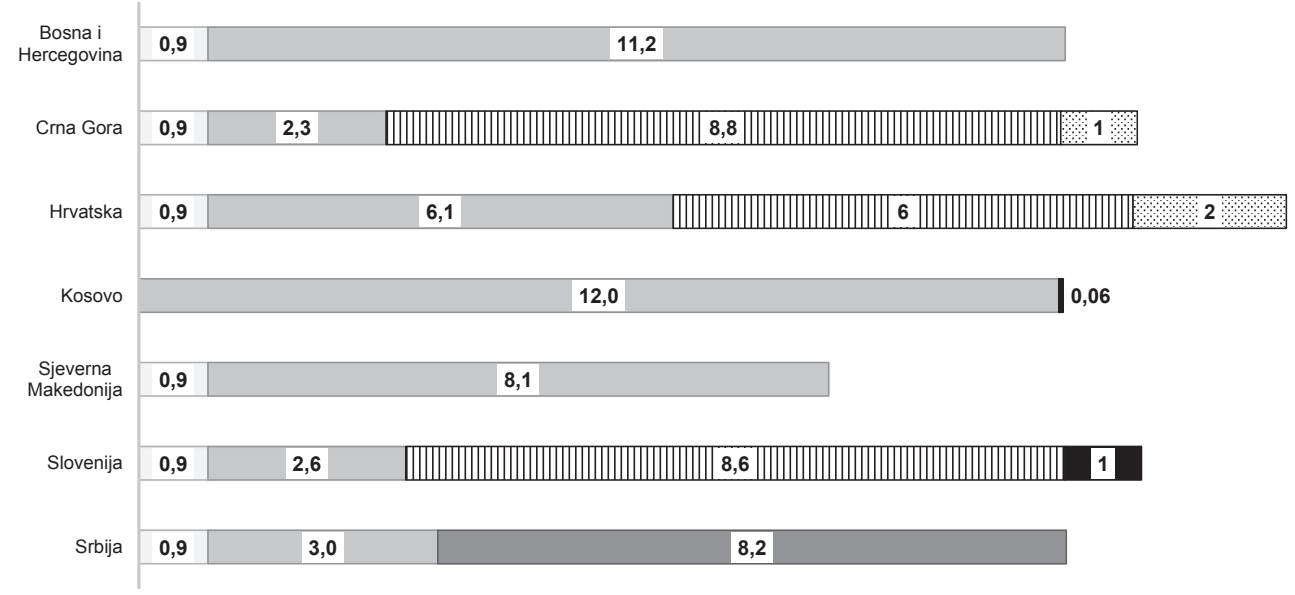

\footnotetext{
$\square$ Rodiljni dopust (prije poroda)

口Roditeljski dopust
}

$\square$ Rodiljni dopust (nakon poroda)

- Dopust za brigu i njegu djeteta

๑vote (neprenosivi mjeseci roditeljskog dopusta)

- Očev dopust

Napomena: Dopusti su plaćeni 100\% prethodne plaće uz iznimku Bosne i Hercegovine gdje su naknade decentralizirane (kreću se od 40 do 100\% prethodne plaće; vidi: Dobrotić i Obradović, 2020.) i Kosova (šest mjeseci dopusta plaćeno je $70 \%$ prethodne plaće, 3 mjeseca $50 \%$ prosječne plaće i tri mjeseca dopusta su neplaćena). Dok u Hrvatskoj na rodiljnu naknadu nema gornje granice, roditeljska naknada iznosi maksimalno HRK 5,654 (0,8 prosječne neto plaće). Crna Gora, Slovenija i Srbija propisuju gornju granicu naknada na način da se ona veže uz prosječnu plaću: Crna Gora (dvije prosječne plaće) i Srbija (tri prosječne plaće) za rodiljni i roditeljski dopust te Slovenija (2,5 prosječne plaće) za roditeljski i očev dopust (rodiljni dopust je izuzet u Sloveniji).

Izvor: Dobrotić (2021.)

(2) Dio zemalja uvodi »produžene« roditeljske dopuste koji mogu imati negativne učinke na sudjelovanje i položaj žena na tržištu rada. Izraženiji se pronatalitetni elementi unutar dizajna politika roditeljskih dopusta uvode $\mathrm{u} \mathrm{Hr}$ vatskoj i Srbiji. Tako se u Hrvatskoj za obitelji s troje ili više djece uvodi trogodišnji, a u Srbiji dvogodišnji dopust (tzv. produženi dopust). ${ }^{6}$ U Hrvatskoj visina roditeljske naknade tijekom produženog dopusta, odnosno nakon što dijete navrši godinu dana (14 mjeseci ukoliko oba roditelja koriste dopust), pada na visinu minimalne naknade, a što nije slučaj u Srbiji gdje je cjelokupan dopust jednako plaćen. Osim toga, u pojedinim zemljama (Hrvatska, Srbija, Crna Gora, Makedonija) dolazi do širenja različitih pronatalitetnih naknada usmjerenih roditeljima s troje ili više djece. Radi se o naknadama koje su podložne čestim promjenama, ovisno o raspoloživim proračunskim sredstvima (u Crnoj Gori

\footnotetext{
${ }^{6}$ Plaćeni se produženi dopusti uvode i u dijelovima BiH i Sloveniji, no oni su umjerenijeg trajanja.
} 
i Makedoniji one se nedavno i ukidaju). Također, u pojedinim su slučajevima takve naknade regionalnog karaktera (npr. Hrvatska; vidi Dobrotić, 2019., 2021.).

(3) Roditelji u netipičnoj i/li nesigurnoj zaposlenosti imaju bolji pristup plaćenim dopustima u zemljama $s$ inkluzivnijim sustavom roditeljskih dopusta. Zemlje se uvelike razlikuju u inkluzivnosti dopusta, $\mathrm{tj}$. mjeri do koje pristup plaćenim dopustima osiguravaju svim roditeljima, neovisno o njihovom statusu na tržištu rada ili drugim obilježjima (Dobrotić i Blum, 2020.; Blum i Dobrotić, 2021.). U zemljama s inkluzivnijim - »mješovitim sustavima« dopusta - koje kombiniraju pravo na placeene dopuste zaposlenih i nezaposlenih/neaktivnih roditelja (npr. Hrvatska, Slovenija), roditelji u netipičnoj i/li nesigurnoj zaposlenosti imaju bolji pristup (adekvatno) plaćenim dopustima
(Slika 2.). Pri tome Slovenija ima inkluzivniji sustav (uvjet za pristup pravu je stalno prebivalište/boravak) $)^{7}$ od Hrvatske gdje je pravo dostupno roditeljima s dugoročnijim prebivalištem/boravkom (tri do pet godina), što potencijalno isključuje migrante. Zemlje koje počivaju na sustavima zasnovanima na zaposlenju (npr. Srbija, ${ }^{8}$ Sjeverna Makedonija ${ }^{9}$ ) pristup plaćenim dopustima ponajprije omogućavaju »tradicionalno« zaposlenim roditeljima. Srbija od 2018. godine omogućava pristup i povremeno/privremeno zaposlenim roditeljima, ali oni teško ostvaruju adekvatnu naknadu. Naime, roditelji sa slabijom povezanošću $\mathrm{s}$ tržištem rada često ne mogu ispuniti kriterij od 18 mjeseci staža osiguranja potreban za punu naknadu (»podosigurani roditelji «) te oni imaju bitno manje rodiljne/roditeljske naknade ili ostaju bez naknada (Slika 2.).

\footnotetext{
${ }^{7}$ Iako, i sam uvjet stalnog prebivališta može biti isključiv za migrante budući da se pravo na dugotrajno boravište može ostvariti tek nakon što je osoba određeno vrijeme već boravila u zemlji (npr. Direktiva 2003/109/ EC predviđa period od pet godina), a što se nedovoljno prepoznaje i u novoj EU direktivi o ravnoteži između poslovnog i privatnog života roditelja i pružatelja skrbi (vidi Dobrotić i Blum, 2019., 2020.).

${ }^{8}$ U Srbiji je 2002. godine ukinuta rodiljna naknada za nezaposlene te se uvodi univerzalno pravo na roditeljsku naknadu, mjera pronatalitetnog karaktera usmjerena svim (zaposlenim i nezaposlenim) roditeljima.

${ }^{9}$ Slično kao i u Srbiji, u Makedoniji je u zadnjem desetljeću postojalo pravo na roditeljsku naknadu pronatalitetnog karaktera, uvjetovano rođenjem trećeg djeteta. Naknada se isplaćivala do djetetove desete godine, odnosno još se uvijek isplaćuje za »zatečene« korisnike prava (DEN 8,362 mjesečno; 68\% prosječne neto plaće; MISSCEO, 2019.).
} 
Slika 2.

Opseg prava na postnatalni dopust prema položaju roditelja na tržištu rada (trajanje dopusta za prvo dijete)

\section{EKVIVALENT U CIJELOSTI PLAĆENOG POST-NATALNOG DOPUSTA 2020 (MJESECI)}

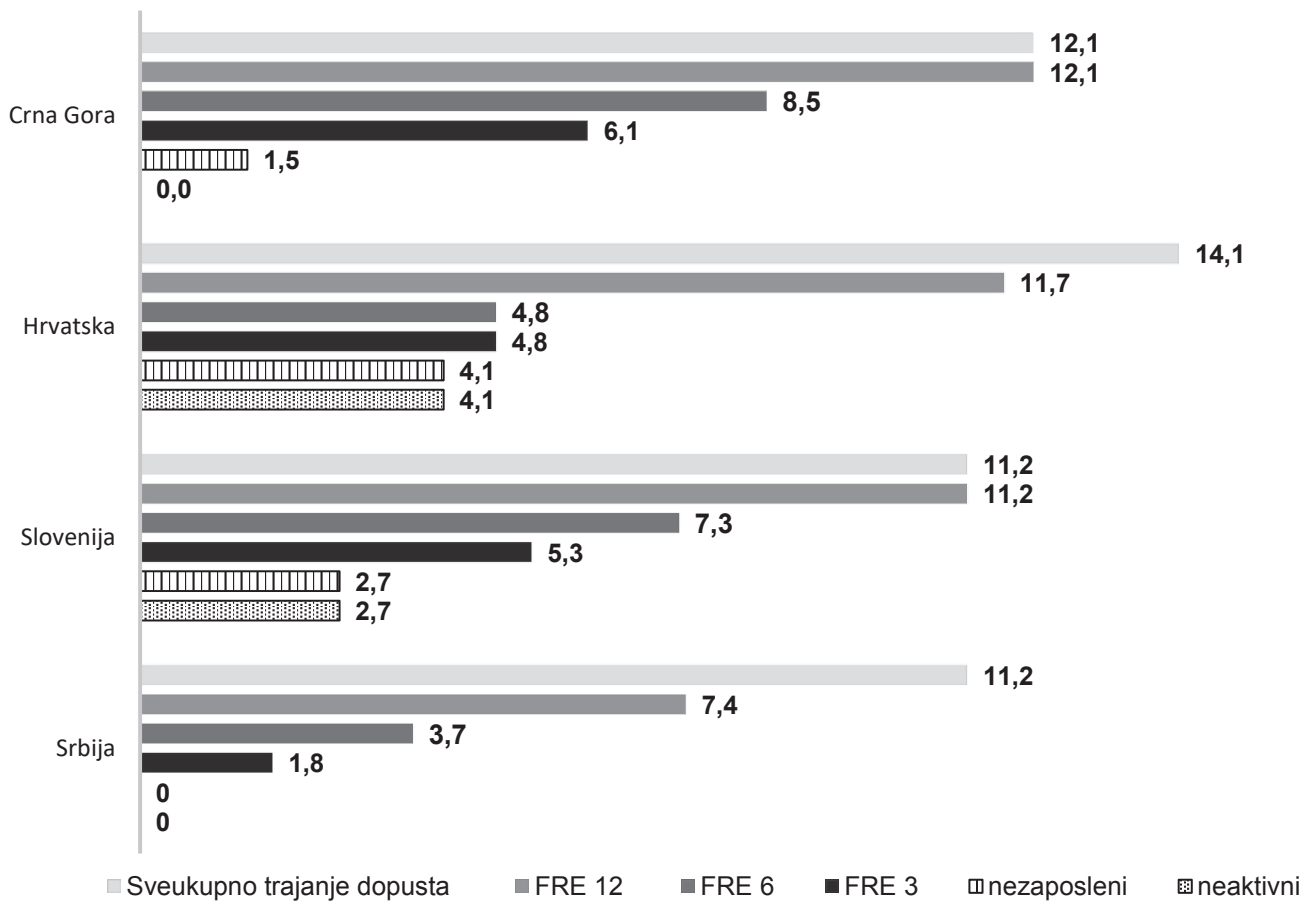

Napomene: Sveukupno trajanje dopusta odnosi se na maksimalno postnatalno trajanje rodiljnog i roditeljskog dopusta zaposlenih roditelja (uključuje kvote, ali ne i očev dopust jer se on može koristiti istovremeno kada i ostali dopusti; FRE (eng. full-rate equivalent) odražava ekvivalent u cijelosti plaćenog postnatalnog dopusta, a računa se kao trajanje dopusta pomnoženo s nadomjesnom stopom dohotka (visina naknade kao udio u prethodnim primanjima), pri čemu je paušalna naknada ili gornja granica naknada tretirana kao udio u prosječnoj neto plaći. FRE dopust izračunat je za (samo)zaposlene osobe koje imaju 12 (FRE 12), šest (FRE 6) i tri (FRE 3) mjeseca neprekinutog staža osiguranja neposredno prije početka dopusta te za "nezaposlene« $\mathrm{i}$ "neaktivne« roditelje (isti opseg prava kao »nezaposleni« imaju i roditelji u neformalnoj ekonomiji te u Hrvatskoj i roditelji izvan sustava rada). Izračun se temelji na jednoj prosječnoj plaći te je u praksi iznos FRE roditelja koji zarađuje više od jedne prosječne plaće u Hrvatskoj, odnosno dvije u Crnoj Gori, 2,5. u Sloveniji i tri u Srbiji niži (dakle, FRE pada s visinom plaće koja nadilazi gornju granicu naknade). Produženi dopusti (npr. Hrvatska, Srbija) nisu prikazani. "Klasično« samozaposleni roditelji imaju jednak opseg prava u svim zemljama izuzev Srbije gdje nemaju pravo na produženi dopust.

Izvor: Dobrotić (2021.) 


\section{POLITIKE RANOG I PREDŠKOLSKOG ODGOJA I OBRAZOVANJA}

Sustavi RPOO-a u europskim zemljama još se uvijek uvelike razlikuju u stupnju razvijenosti te ključnim institucionalnim obilježjima. Njihove se sličnosti i razlike u pravilu razmatraju temeljem pet skupina komparativnih pokazatelja: 1) dostupnost (npr. raspoloživost mjesta, odnosno udio djece obuhvaćene predškolskim programima), 2) pristupačnost (npr. pravo djeteta na RPOO - kroz jamstvo mjesta ili obavezan dio programa; kriteriji upisa), 3) priuštivost (npr. visina subvencija; gornja granica na roditeljsko sudjelovanje u cijeni programa), 4) fleksibilnost (npr. usklađenost radnog vremena RPOO-a s potrebama zaposlenih roditelja) i 5) kvaliteta (npr. maksimalna veličina odgojno-obrazovnih skupina, potrebna obrazovna razina odgojitelja) (usp. Eurydice i Eurostat, 2014.; Working Group on Early Childhood Education and Care, 2014.; Dobrotić i sur., 2018.; Yerkes i Javornik, 2018.).

Pristup priuštivim i kvalitetnim uslugama RPOO-a omogućava ravnopravno sudjelovanje roditelja na tržištu rada i jednake mogućnosti svakom djetetu. Pristupačni, kvalitetni i priuštivi programi RPOO-a olakšavaju usklađivanje obiteljskih obaveza i plaćenog rada i čine rad »isplativim« te upravo zemlje s razvijenijim sustavima, a posebice za djecu jasličke dobi, pokazuju najviše stope zaposlenosti žena i manju opterećenost obiteljskim obavezama. Dostupni i priuštivi programi čine pristup RPOO-u - ključnom za razvoj kognitivnih i socijalnih vještina djece - lakšim i za djecu iz obitelji nižeg socioekonomskog statusa. Zemlje uvode različite mehanizme kojima osiguravaju pristupačnost i priuštivost programa, a kako bi se svakom djetetu osiguralo pravo na RPOO. Ponajprije se radi o jamstvu mjesta u RPOO-u ili obaveznom dijelu programa te javnom subvencioniranju izdataka vezanih uz skrb - kroz uvođenje besplatnih programa, maksimalnog iznosa roditeljskog sudjelovanja u cijeni predškolskog programa ili progresivnih skala pri određivanju visine subvencija. Ti mehanizmi smanjuju društvene razlike u pristupu predškolskim programima (usp. Working Group on Early Childhood Education and Care, 2014.; Dobrotić, 2015., 2021.; Dobrotić i sur., 2018.; Yerkes i Javornik, 2018.; Eurydice, 2019.).

Međuodnos između roditeljskih dopusta i usluga RPOO-a iznimno je bitan s aspekta rodne ravnopravnosti te je bitno da se ta dva sustava razvijaju zajedno kako bi se izbjegao jaz između dobi djeteta prilikom početka jamstva uključivanja u predškolski program i završetka dobro plaćenih roditeljskih dopusta (tzv. jaz u skrbi; vidi Koslowski i sur., 2020.). Ukoliko po završetku dobro plaćenih roditeljskih dopusta ne postoji pristup priuštivim i kvalitetnim uslugama RPOO-a, povećavaju se šanse za »ispadanje« roditelja (primarno žena) $\mathrm{s}$ tržišta rada. Drugim riječima, politike roditeljskih dopusta koje ne čine dio koherentnog »paketa« politika skrbi za djecu predškolske dobi »proizvode« jaz u skrbi i otežavaju sudjelovanje roditelja na tržištu rada (Dobrotić, 2015., 2021.).

\section{Usluge ranog i predškolskog odgoja i obrazovanja u postjugoslavenskim zemljama}

Slično politikama roditeljskih dopusta, sustav RPOO-a počinje se intenzivnije razvijati s razdobljem socijalizma. Ipak, komparativno gledano, u pogledu broja uključene djece sustav ostaje slabije razvijen. Primjerice, dok je 1990. godine u Češkoj i Slovačkoj više od 75\%, a u Mađarskoj $85 \%$ djece vrtićke dobi (3-6) bilo uključeno u redovne predškolske programe, dostupnost je usluga u Jugoslaviji bila bitno niža - tek je $23 \%$ djece vrtićke dobi bilo obuhvaćeno redovnim predškolskim programima (Zrinščak, 2002.). Postojale su i izražene regionalne nejednakosti u dostupnosti pro- 
grama, a koje su bile jasan odraz ekonomske moći i fiskalnih kapaciteta pojedine sredine (usp. Stropnik, 2001.; UNICEF, 2012.; Dobrotić i sur., 2018.) budući da je sustav RPOO-a od samih začetaka decentraliziran te o osnivanju i financiranju predškolskih programa ponajprije brinu općine/gradovi. Uslijed nedostatnih kapaciteta pribjegavalo se selektivnim praksama pri upisu djece polazeći od glavne funkcije sustava, usklađivanja obiteljskih obaveza i plaćenog rada, prednost se upisa davala djeci zaposlenih roditelja. Kao što se prikazuje u nastavku, suprotno politikama roditeljskih dopusta, koje su bile predmetom čestih reformi, sustav RPOO-a nakon 1990. godine bilježi bitno manje promjena.

Postjugoslavenske zemlje nisu razvile dostupne i pristupačne usluge RPOO-a ključne za (kontinuirano) sudjelovanje žena na tržištu rada te omogućavanje jednakih mogućnosti svakom djetetu. Unazad tri desetljeća tek Slovenija bilježi znatnija ulaganja u RPOO te jedina u regiji doseže smjernice EU-a - 2019. godine jasličkim programima bilo je obuhvaćeno $66,5 \%$ djece, vrtićkim programima 90,7\% djece te $94,1 \%$ trogodišnjaka i četverogodišnjaka (SURS, 2020.; usp. Slika 3.). Jedina uvodi i jamstvo uključivanja svakog djeteta u RPOO po završetku dobro plaćenih roditeljskih dopusta (od 1996. godine), a što je svrstava među svega pet europskih zemalja koje nemaju jaz u skrbi (Stropnik, 2018.; Eurydice, 2019.; Tablica 2.). U ostalim zemljama usluge RPOO-a nedostupne su većini djece (Slika 3.). Štoviše, postepeni je rast obuhvaćenosti djece programima bio velikim dijelom rezultat samog smanjivanja populacije djece predškolske dobi te tek unazad nekoliko godina pojedine zemlje, potpomognute od strane međunarodnih aktera, počinju vidljivije ulagati u nove kapacitete (npr. Crna Gora, Hrvatska, Srbija). Stoga, sagledamo li kriterije upisa u predškolske programe, zemlje nadalje pribjegavaju selektivnim praksama i prio- ritet pri upisu u redovne programe nadalje daju djeci »tradicionalno« zaposlenih roditelja. Izvan sustava najčešće ostaju djeca nižeg socioekonomskog statusa, kao i djeca koja žive u slabije razvijenim te ruralnim i depopuliziranim područjima (usp. Prica i sur., 2014.; Mladenović, 2016.; Dobrotić i sur., 2018.). Za svu se djecu u pojedinim zemljama organiziraju tek obavezni programi predškole, koji su kratkog trajanja i čija je primarna svrha priprema djeteta za školu (Tablica 2.).

Elementi priuštivosti programa RPOO-a u pojedinim zemljama slabe čime se otvara prostor većim regionalnim nejednakostima u visini subvencija. Unazad nekoliko godina Crna Gora i Srbija gradovima/općinama daju veću autonomiju u definiranju visine subvencija predškolskih programa, otvarajući prostor za prebacivanje sve većeg dijela cijene boravka djeteta u RPOO-u na roditelje. Tako Crna Gora 2016. godine otvara mogućnost da se od roditelja traži sudjelovanje u podmirivanju same cijene boravka djeteta u predškolskom programu, dok Srbija 2017. godine ukida gornju propisanu granicu roditeljskog sudjelovanja u cijeni programa (prethodno je iznosila maksimalno $20 \%$ ekonomske cijene programa). Takve reforme mogu dovesti do toga da programi RPOO-a postanu slabije priuštivi, posebice djeci iz obitelji nižeg socioekonomskog statusa te djeci koja žive u slabije razvijenim sredinama, a što potvrđuje iskustvo Hrvatske koja je takvima praksama pribjegla još 1960-ih godina (usp. Baran i sur., 2011.; Dobrotić i sur., 2018.). Slovenija je jedina definirala jasnu metodologiju izračuna ekonomske cijene programa i visine subvencija, koja temelje na progresivnoj skali te vodi računa o socioekonomskom statusu obitelji. Na taj je način smanjila regionalne razlike u cijeni predškolskih programa (Stropnik, 2001.), a sustav je postao priuštiviji roditeljima nižeg socioekonomskog statusa te time pristupačniji svoj djeci (usp. Abrassart i Bonoli, 2015.). 
Slika 3.

Obuhvaćenost djece uslugama ranog i predškolskog odgoja i obrazovanja prema dobnim skupinama (0-2 godine; 3 godine do polaska u osnovnu školu)

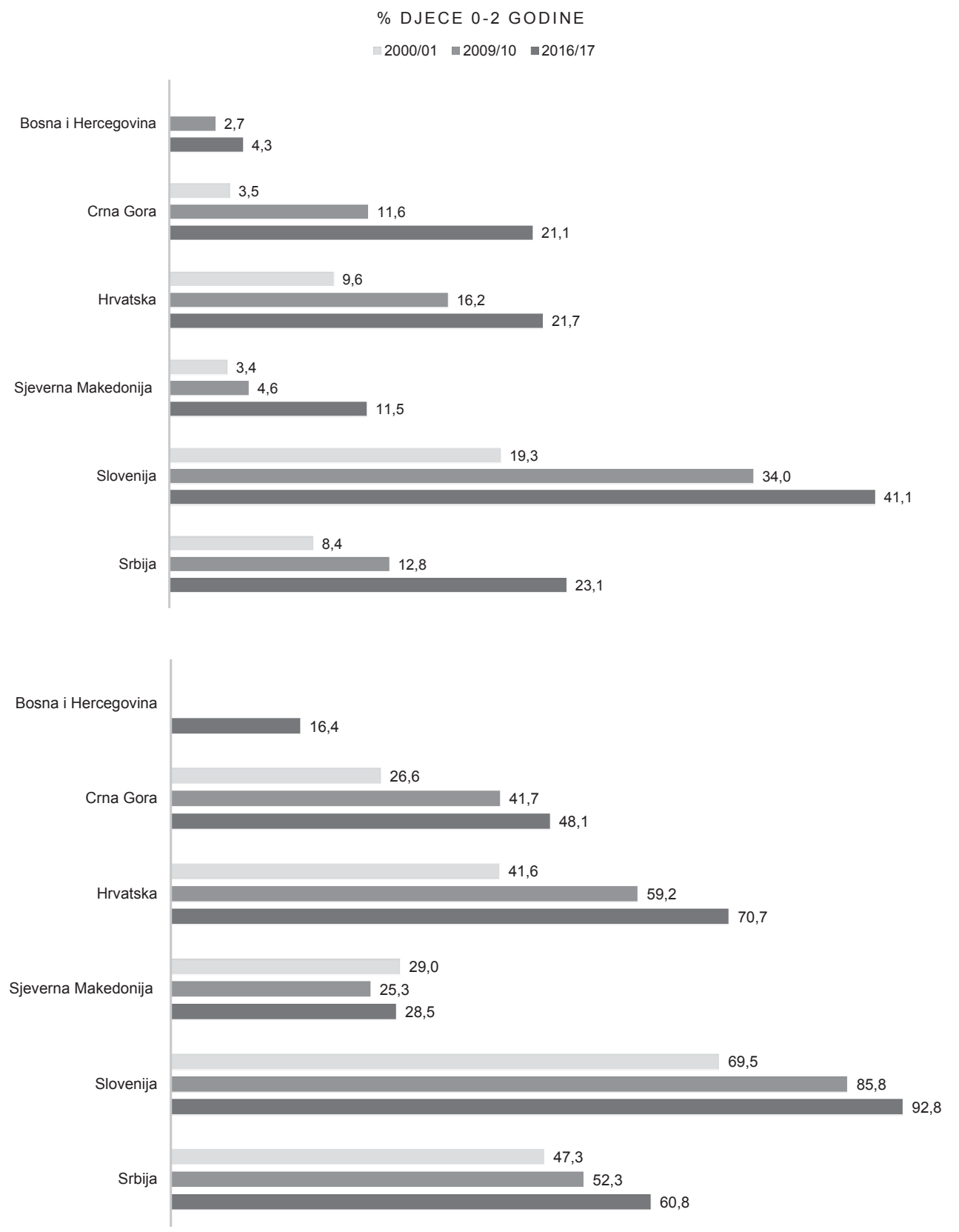

Izvor: TransMonee (2019.; preuzeto iz Dobrotić, 2021.) 
Tablica 2.

Izabrani pokazatelji pristupačnosti us/uga ranog i predškolskog odgoja i obrazovanja: jamstvo mjesta, obavezni program pripreme za školu i jaz u skrbi za djecu predškolske dobi

\begin{tabular}{|c|c|c|c|c|c|}
\hline & \multirow{2}{*}{$\begin{array}{l}\text { Jamstvo } \\
\text { mjesta }\end{array}$} & \multicolumn{2}{|c|}{$\begin{array}{c}\text { Obavezni program pripreme } \\
\text { za školu: }\end{array}$} & \multicolumn{2}{|c|}{$\begin{array}{l}\text { Mjeseci jaza između dobi } \\
\text { jamstva mjesta i kraja: }\end{array}$} \\
\hline & & $\begin{array}{c}\text { dob } \\
\text { (početak } \\
\text { implementacije) }\end{array}$ & tjedni sati & $\begin{array}{l}\text { roditeljskih } \\
\text { dopusta }\end{array}$ & $\begin{array}{c}\text { dobro plaćenih } \\
\text { roditeljskih } \\
\text { dopusta }\end{array}$ \\
\hline $\begin{array}{l}\text { Bosna i } \\
\text { Hercegovina }\end{array}$ & - & \multicolumn{2}{|c|}{ decentralizirani sustav ${ }^{1}$} & $\infty$ & $\infty$ \\
\hline Crna Gora & - & 5 (2011.) & 3 sata/dan ${ }^{2}$ & $\infty$ & $\infty$ \\
\hline Hrvatska & - & 5,5 (2014.) & 150-250 sati ${ }^{3}$ & $\infty$ & $\infty$ \\
\hline Slovenija & 11 mjeseci $^{4}$ & $5(2018)$. & 240 sati & 0 & 0 \\
\hline Srbija & - & $5,5(2007 .)^{5}$ & $\begin{array}{l}4 \text { sata/dan } 9 \\
\text { mjeseci }^{5}\end{array}$ & $\infty$ & $\infty$ \\
\hline
\end{tabular}

Napomene: Kosovo i Sjeverna Makedonija nisu uključene u tablicu budući da ne postoji jamstvo mjesta u RPOO-u ili obavezan program pripreme za školu; $\infty$ ne postoji jamstvo mjesta u RPOO-u.

1= iako je okvirnim zakonodavstvom o ranom i predškolskom odgoju i obrazovanju propisano kako sva djeca u godini pred polazak u osnovnu školu obavezno polaze predškolski program, kantonalni zakoni još uvijek nisu u potpunosti usklađeni i ova odredba nije uvedena i implementirana na području cijele BIH (npr. Hercegovačko-neretvanska županija nije uskladila zakonodavstvo, dok je Kanton Središnja Bosna odgodio implementaciju); $\mathbf{2 =}$ trajanje je programa regulirano 2017. godine; $3=$ redovno trajanje programa je 250 sati u godini prije polaska u osnovnu školu, a iznimno 150 sati (u slučaju malog broja djece, otežanih uvjeta dolaska ili boravka djece ili drugih objektivnih teškoća); program se mora organizirati na području unutar 20 kilometara od stanovanja djeteta; 4= realizira se ukoliko ima dovoljno djece da se oformi nova odgojnoobrazovna skupina (ili raspisivanjem koncesije); $5=\mathrm{u}$ trenutku uvođenja propisano je da program traje 4 sata dnevno kroz 6 mjeseci, da bi 2009. godine bio produžen na 4 sata tjedno kroz 9 mjeseci.

Izvor: Dobrotić (2019.)

\section{KLJUČNI NALAZI I NJIHOVE IMPLIKACIJE}

Sagledamo li strukturu trenutnih dopusta usmjerenih roditeljima, možemo vidjeti kako postjugoslavenske zemlje imaju relativno izdašne sheme dopusta, posebice stave li se u komparativnu perspektivu s drugim europskim zemljama (usp. Koslowski i sur., 2020.; Dobrotić i Stropnik, 2020.). Štoviše, uz iznimku produženih dopusta (posebice u Hrvatskoj) radi se o dopustima umjerenog trajanja koji olakšavaju povezanost majki s tržištem rada. No, pristup tim dopustima, ali i u uslugama RPOO-a, primarno imaju roditelji u »standardnoj《 zaposlenosti te sam dizajn politika nedovoljno prepoznaje specifičnosti rastućeg broja roditelja u netipičnoj i nesigurnoj zaposlenosti, ali i heterogenost obiteljskih oblika i životnih stilova. Brojni roditelji u postjugoslavenskim zemljama stoga nemaju (adekvatan) pristup roditeljskim pravima, što je uvelike povezano već sa samim dizajnom politika roditeljskih dopusta i sustava RPOO-a koje primarno polaze od situacije »prosječnog zaposlenika/kućanstva « - u ovom slučaju od heteronormativne vizije obitelji »dvostrukog hranitelja čiji su odrasli članovi $\mathrm{u}$ »tradicionalnom « radnom odnosu (usp. Bártová i Emery, 2018.). Drugim riječima, kreirane su na način da »stvaraju « i reproduciraju rodne i društvene nejednakosti. Pri tome je važno naglasiti kako je situacija na gotovo svim dimenzijama dizajna politika 
skrbi za djecu predškolske dobi povoljnija u Sloveniji, dok se u drugim zemljama roditelji suočavaju s nizom prepreka. Kako bi se nadišle nejednakosti u mogućnostima istovremena sudjelovanja u skrbi i zaposlenosti različitih skupina roditelja zemalja, potrebno je:

$\rightarrow$ U zemljama koje sustave dopusta temelje isključivo na zaposlenju, rekonceptualizirati politike roditeljskih dopusta te ih (ponovno) redefinirati kao pravo na skrb i socijalnu zaštitu, a ne samo kao pravo iz radnog odnosa (usp. Doucet, 2019.).

$\rightarrow$ Razviti inkluzivnije sheme roditeljskih dopusta koje će svim roditeljima omogućiti adekvatan pristup i opseg prava na plaćene dopuste, a time i same mogućnosti stvarnog korištenja dopusta (npr. putem uvođenja očevih kvota/dopusta neovisnih o majčinom statusu na tržištu rada, jednakih prava istospolnih roditelja, omogućavanja prijenosa dopusta na treću osobu kod jednoroditeljskih obitelji, adekvatnijih prava roditelja u nesigurnoj/netipičnoj zaposlenosti što uključuje i blaže kriterije pristupa pravima).

$\rightarrow$ Osigurati pristup priuštivim i kvalitetnim uslugama RPOO-a svoj djeci, a ponajprije osigurati jamstvo mjesta svakom djetetu te uvesti elemente priuštivosti unutar samih sustava RPOO-a (npr. subvencije koje će počivati na progresivnoj skali te definirati i maksimalan iznos roditeljskog sudjelovanja u cijeni programa koji može propisati općina/grad).

Konačno, same politike roditeljskih dopusta i usluga RPOO-a nisu dovoljne za uspostavljanje održivog odnosa između skrbi i zaposlenja. Rodne nejednakosti u skrbi i zaposlenosti dodatno pojačavaju tradicionalne vrijednosti i norme te organizacijska kultura »stalne dostupnosti«. Stoga je nužna podrška na radnom mjestu, pri čemu ključnu ulogu igraju dodatne mjere poslodavaca usmjerene usklađivanju obiteljskih obaveza i plaćenog rada, ali i za »roditelje prijateljsko« radno okruženje. Organizacijska kultura »stalne dostupnosti«, odnosno očekivanje da će se zaposlenici posvetiti isključivo poslu povećava sukob između obiteljskih obaveza i plaćenog rada. Štoviše, u takvim se organizacijama očevi nerijetko susreću s brojnim preprekama u ostvarivanju prava na dopuste i iste ne koriste (npr. negativne reakcije poslodavaca i suradnika, strah od otkaza), dok su majke izloženije diskriminatornim praksama i u većem riziku od »ispadanja« s tržišta rada. Konačno, opća »kultura skrbi« također definira roditeljske prakse. Primjerice, očevi se češće susreću s preprekama pri korištenju dopusta u zemljama u kojima dominiraju tradicionalni ideali roditeljstva, odnosno stroge norme o primarnoj ulozi majke u skrbi i oca u »privređivanju«, što vodi održavanju rodnih nejednakosti (Dobrotić i Varga, 2018.; Koslowski i sur., 2019.).

\section{LITERATURA}

Abrassart, A., \& Bonoli, G. (2015). Availability, cost or culture? Obstacles to childcare services for low-income families. Journal of Social Policy, 44(4), 787-806. https://doi.org/10.1017/ S0047279415000288

Baran, J., Dobrotić, I., \& Matković, T. (2011.). Razvoj institucionaliziranog predškolskog odgoja u Hrvatskoj: promjene paradigme ili ovisnost o prijeđenom putu? Napredak: časopis za pedagogijsku teoriju i praksu, 152(3-4), 521-539. https://hrcak.srce.hr/82790

Bártová, A., \& Emery, T. (2018). Measuring policy entitlements at the micro-level: Maternity and parental leave in Europe. Community, Work \& Family, 21(1), 33-52. https://doi.org/10.1080/13 668803.2016 .1202196

Blum, S., \& Dobrotić, I. (2021). The inclusiveness of social rights: The case of leave policies. Social Inclusion, 9(2), 222-226. https://doi. org/10.17645/si.v9i2.4523

Blofield, M., \& Franzoni, J. M. (2015). Maternalism, co-responsibility, and social equity: A typology of work-family policies. Social Politics, 22(1), 38-59. https://doi.org/10.1093/sp/jxu015 
Brandth, B., \& Kvande, E. (2019). Flexibility: Some consequences for father's caregiving. U P. Moss, A.-Z. Duvander \& A. Koslowski (Eds.), Parental Leave and Beyond: Recent international developments, current issues and future directions (pp. 205-222). Bristol: Policy Press.

Council Resolution on a strategic framework for European cooperation in education and training towards the European Education Area and beyond (2021-2030). Official Journal of the European Union C 66/01. Available at https://eur-lex.europa.eu/legal-content/EN/TXT/PDF/?uri=uriserv:OJ.C_.2021.066.01.0001.01.ENG

Dobrotić, I. (2015). Politike usklađivanja obiteljskih obaveza i plaćenog rada i položaj roditelja na tržištu rada. Revija za socijalnu politiku, 22(3), 353-374. https://doi.org/10.3935/rsp.v22i3.1258

Dobrotić, I. (2019). Childcare-related policies design and changing faces of social and gender inequalities in childcare in the post-Yugoslav countries. Technical Report - InCare project. Available at https://www.incare-pyc.eu/2020/08/29/report-on-social-and-gender-inequalities-in-childcare-related-policies-design-in-the-post-yugoslav-countries/

Dobrotić, I. (2021). „Rastuća (ne)vidljiva većina“? Nesigurna i netipična zaposlenost $i$ roditeljstvo. Available at: https://www.incare-pyc.eu/ wp-content/uploads/2021/02/InCARE-report-final-web.pdf

Dobrotić, I., \& Blum, S. (2019). A social right? Access to leave and its relation to parent's labour market position. In P. Moss, A.-Z. Duvander \& A. Koslowski (Eds.), Parental Leave and Beyond: Recent international developments, current issues and future directions. Bristol: Policy Press.

Dobrotić, I., \& Blum, S. (2020). Inclusiveness of parental leave benefits in 21 European countries: Measuring social and gender inequalities in leave eligibility. Social Politics: International Studies in Gender, State \& Society, 27(3), 588-614. https://doi.org/10.1093/sp/jxz023

Dobrotić,I., Matković, T., \& Menger, V. (2018). Analiza pristupačnosti, kvalitete, kapaciteta i financiranja sustava ranoga i predškolskog odgoja i obrazovanja u Republici Hrvatskoj. Zagreb: Ministarstvo za demografiju, obitelj, mlade i socijalnu politiku.

Dobrotić, I., \& Obradović, N. (2020). The exclusionary side of (women's) social citizenship in Southeastern Europe: Childcare policy development in Bosnia-Herzegovina and gender, social and territorial inequalities. Southeast European and Black Sea Studies, 20(3), 411-430. https://doi.org/ 10.1080/14683857.2020.1805890
Dobrotić, I., \& Varga, M. (2018). Zašto su važni očevi dopusti i kvote? Komparativni pregled shema dopusta za očeve u europskim zemljama te čimbenika i učinaka njihova korištenja. Revija za sociologiju, 48(2), 209-237. https://doi. org/10.5613/rzs.48.2.4

Doucet, A., McKay, L., \& Mathieu, S. (2019). Re-imagining parental leave: a conceptual "thought experiment”. In P. Moss, A.-Z. Duvander \& A. Koslowski (Eds.), Parental leave and beyond: recent international developments, current issues and future directions (pp. 333-352). Bristol: Policy Press.

European Council. (2002). Presidency Conclusions: Barcelona European Council, 15-16 March 2002. Available at https://ec.europa.eu/commission/presscorner/detail/en/PRES_02_930

Eurydice, \& Eurostat. (2014). Key Data on Early Childhood and Care in Europe. Available at https://ec.europa.eu/eurostat/web/products-statistical-books/-/EC-01-14-484?inheritRedirect=true

Ferragina, E. (2020). Family policy and women's employment outcomes in 45 high-income countries: A systematic qualitative review of 238 comparative and national studies. Social Policy \& Administration, 54(7), 1016-1066. https://doi. org/10.1111/spol.12584.

Galtry, J., \& Callister, P. (2005). Assessing the optimal length of parental leave for child and parental well-being: How can research inform policy?. Journal of Family Issues, 26(2), 219246. https://doi.org/10.1177/0192513X04270344

Ghysels, J., \& Van Lancker, W. (2011). The unequal benefits of activation: An analysis of the social distribution of family policy among families with young children. Journal of European Social Policy, 21(5), 472-485. https://doi. org/10.1177/0958928711418853

Gornick, C. J., \& Meyers, K. M. (2003). Families that work. Policies for reconciling parenthood and employment. New York: SAGE.

Huerta, M. C., Adema, W., Baxter, J., Han, W.-J., Lausten, M., Lee, R., \& Waldfogel, J. (2014). Fathers' leave and fathers' involvement: Evidence from four OECD Countries. European Journal of Social Security, 16(4), 308-346. https://doi. org/10.1177/138826271401600403

Koslowski, A., Blum, S., Dobrotić, I., Kaufman, G., \& Moss, P. (2020). International Review of Leave Policies and Related Research 2020. Available at https://www.leavenetwork.org/annual-review-reports/

Koslowski, A., Duvander, A.-Z., \& Moss, P. (2019). Parental leave and beyond: recent international 
developments, current issues and future directions. In P. Moss, A.-Z. Duvander \& A. Koslowski (Eds.), Parental leave and beyond: recent international developments, current issues and future directions (pp. 353-370). Bristol: Policy Press.

Korintus, M., \& Stropnik, N. (2009). Hungary and Slovenia: Long leave or short?. In S. B. Kamerman \& P. Moss (Eds.), The Politics of Parental Leave Policies (pp. 135-157). Bristol: Policy Press.

McKay, L., Mathieu, S., \& Doucet, A. (2016). Parental-leave rich and parental-leave poor: Inequality in Canadian labour market based policies. Journal of Industrial Relations, 58(4), 543-562. https://doi.org/10.1177/0022185616643558

Mutual Information System on Social Protection of the Council of Europe. (2019). Family benefits. Available at https://rm.coe.int/en-9-summaryrev-2019/16809a5169

Mladenović, B. (2016). Koliko košta poludnevni diversifikovani program u predškolskom vaspitanju i obrazovanju. Beograd: UNICEF Srbija.

O’Brien, M., \& Wall, K. (Eds.). (2017). Comparative Perspectives on Work-Life Balance and Gender Equality: Fathers on Leave Alone. London: Springer Open.

Organisation for Economic Co-operation and Development. (2011). Doing Better for Families. Paris: OECD Publishing.

Pavolini,E., \& Van Lancker, W. (2018). The Matthew effect in childcare use: A matter of policies or preferences?. Journal of European Public Policy, 25(6), 878-893. https://doi.org/10.1080/1350 1763.2017.1401108

Prica, I., Čolić, L., \& Baronijan, H. (2014). Studija o ulaganju u rano obrazovanje djece u Crnoj Gori. Podgorica: UNICEF Crna Gora.
Stropnik, N. (2001). Child care in Slovenia: An example of a successful transition. Child: Care, Health and Development, 27(3), 263-278. https://doi. org/10.1046/j.1365-2214.2001.00211.x

Stropnik, N. (2018). Slovenia country note. In S. Blum, A. Koslowski, A. Macht \& P. Moss (Eds.), International Review of Leave Policies and Research 2018. Available at https://www.leavenetwork.org/ annual-review-reports/archive-reviews/

Statistični urad Republike Slovenije. (2020). Otroci vključeni v vrtce. Available at https://pxweb.stat. si/SiStatData/pxweb/s1/Data/Data/0952541S.px/

United Nations Children's Fund. (2012). Investing in early childhood education in Serbia: Costing models for ensuring preschool education for All. UNICEF Working Paper (September). Belgrade: UNICEF Serbia.

Working Group on Early Childhood Education and Care. (2014). Proposal for key principles of a Quality Framework for Early Childhood Education and Care. Brussels: European Commission. Available at https://ec.europa.eu/assets/eac/education/policy/strategic-framework/ archive/documents/ecec-quality-framework_ en.pdf

Yerkes, M. A., \& Javornik, J. (2018). Creating capabilities: Childcare policies in comparative perspective. Journal of European Social Policy, 29(4), 529-544. https://doi.org/10.1177/09589 28718808421

Zrinščak, S. (2002). Socijalna i obiteljska politika u tranzicji. Revija za socijalnu politiku, 9(1), 107115. https://doi.org/10.3935/rsp.v9i1.196

Priredila: Ivana Dobrotić 